\title{
A Fight for Gender Equality within the United States' Government
}

\author{
Yanuar Albertus, Ni Made Citra Kusuma Dewi, Bastiano \\ Giveraldy Ginting, Anastasia Devina Hartono, Naomi Devi \\ Larasati, Devira Adventia Primaristy
}

\author{
Universitas Airlangga
}

\begin{abstract}
The stereotypes that women belongs to household chores cause people to doubt the capability of women to work in the government, therefore they are unable to obtain job in politics or government sector as men do. Therefore, this article aims to explain how women are perceived and treated in the political system of the United States, especially in Congress. This objective will be achieved through a comprehensive analysis and literature reading of the current situation of women in the United States' government system. Based on the existing literature and data studies, the authors argued that the problem of gender inequality remains in the United States due to inequality in wage, health, security, and especially politics. Thus, the author's team provides three ways as a solution to change the existing political system. First, by conducting a campaign focusing on gender equality issues, which can be done through social media or directly in the community. Second, the use of electronic petitions for the government to pay attention to issues of gender equality. Third, a peace movement that focuses on gender equality issues.
\end{abstract}

Keywords: Gender equality, women's right, the United States, the Congress.

Stereotipe bahwa wanita hanya mampu mengerjakan pekerjaan rumah membuat masyarakat meragukan kapabilitas wanita untuk bekerja dalam pemerintahan. Wanita dianggap tidak mampu untuk bekerja dalam bidang politik maupun pemerintahan sebagus pria. Oleh karenaitu, artikel ini bertujuan untuk menjelaskan bagaimana wanita dipersepsikan dan diperlakukan dalam pemerintahan Amerika Serikat terutama dalam Kongres. Tujuan ini akan dicapai melalui analisis komprehensif dan bukti-bukti literatur mengenai situasi terkini wanita dalam sistem pemerintahan Amerika Serikat. Berdasarkan studi literatur dan data yang ada, tim penulis berargumen bahwa kesetaraan gender masih belum tercapai di Amerika Serikat karena adanya ketimpangan dalam hal pemberian upah, sistem kesehatan, keamanan, dan terutama politik. Dengan demikian, tim penulis memberi solusi untuk mengubah sistem politik yang ada melalui tiga cara. Pertama, mengadakan kampanye yang berfokus mengenai isu kesetaraan gender. Kampanye ini dapat dilakukan melalui media sosial atau secara langsung di tengah-tengah masyarakat. Kedua, penggunaan petisi elektronik bagi pemerintah agar memberikan perhatiannya pada permasalahan kesetaraan gender. Ketiga, pergerakan perdamaian yang berfokus kepada permasalahan kesetaraan gender.

Kata kunci: kesetaraan gender, hak wanita, Amerika Serikat, Kongres 


\section{Introduction}

This paper is started will start by clarifying the meaning of gender and gender inequality. Gender, as opposed to sex, refers to the roles and responsibilities of men and women that are constructed by society (United Nations Educational, Scientific, and Cultural Organization 2003). Therefore, the concept of gender is linked to masculinity and femininity as opposed to sex that mainly speaks about a person's biological differences which is determined by birth such as a man and a woman. GenderThe construction of gender has put women at disadvantageous position, because women's freedom to choose work is limited only to household chores or other positions deemed as that are seen femininfeminine; hence, it leads to e. This lead to what we identify as gender inequality. It refers Gender inequality is thtoe social process in which people are treated differently under the similar circumstances based on their perceived gender. Therefore, feminism is an analysis theory aimed to examine various social phenomena about gender bias or role that comes with a person's sex. Using a set of analytical tool with gender as the basis, feminism tried to reveal the fact that there is an inequality in the society, specifically between men and women (True 2001). As a matter of fact, inequality between men and women has affected various part of women's life, especially human rights. Society's stigma in the society that men have higher social status and higher chances to reach prosperity is one of the reasons feminism was formed in the first place (Jackson and Sorensen 2013). In its development, feminism that once only thrived domestically has started to expand and affect people globally. Feminism issues in various countries have started to be addressed by many policies relevant to the achievement of equality in various areas of human life. In some countries, like Indonesia and Germany, a woman leader is no longer unprecedented. Women's rights are starting to be fought for, even fulfilled, especially in politics and government. The bureaucracy, which can guarantee and support women empowerment, is on the rise, so feminism-related phenomena feminism can be comprehensively parsed (United Nations Department of Economic and Social Affairs 2005).

Ridgeway (2011 in United Nations Development Programme 2013) stated that gender inequality is caused by gender norms and its stereotypes that reinforce gendered identities; thus, constraining the behavior of men and women in certain ways and later leading tothat lead to inequality. Further, gender inequality has always been a contested problem for all countries, whether developed or developing 
country. According to Kamrany and Robinson (2012), only 4 (four) countries out of 135 in the world has achieved gender equality. The four countries are Costa Rica, Cuba, Sweden, and Norway. This clearly shows that the problem of gender inequality has not been addressed properly by all countries in the world. However, some researchers agree that the problem of gender inequality problems are is more acute in developing countries than in developed countries (Jayachandran 2015; Dea 2016). Jayachandran (2015) argueds that the disparities in health, education, and bargaining power in marriage tends to be larger in developing countries. The problem of gender inequality in developing countriesIt is further is heightened by the problem of certain cultural practices that favor men over women. Dea (2016) stated that if a country is successful in minimizing or even closing the gender gap, the countryit would have has a better chance of develop through alleviating poverty. This implicitly means that a developed country should have a small number of gender gap, because that country is successful in alleviating poverty.

However, that is not the case with United States of America. Despite being the only superpower country with a developed economy in the world and having great education level and intensity of values and ethics cultivation, United States become one of the countries with high level gender inequality (Time Magazine 2015). Unfortunately, in a research done by the World Economic Forum in 2016, United States only ranked 73 out of 144 countries in women's political empowerment. Many gender inequality-related problems, such as women's wage being lower than men's and women's marginalized role in the United States' government, become an important focus in the struggle to reach equality between men and women. This condition is also supported by many negative stereotypes on females that thrive among the society (Biddle, 2017). Those cases show that there is an emergence of a causal relation that sees a woman as an entity who does not have enough capability and competence to work and reach her own success. As an influential country, the authors argue that the United States political system which is still based on the stigma and stereotype that men are better be revised. The existence of normative feminism can be a guide for the people to act, so their social and political lives can change accordingly.

Therefore, social and political phenomena currently happening in the United States should be analyzed comprehensively with feminism theory. Through the literature reading, the authors aim to explore how women are truly perceived in the United States political system 
to find the right solution to solve gender inequality problems. Many advocacy efforts that are devoted to women are also the main goal of reaching equality between men and women. By referring to its emancipatory nature, the authors are confident that feminism could help the people of the United States in parsing the social-political phenomena according to the relevance with the current period. When this equality has been achieved, the authors believe that the ideal social and political life will occur; hence, women can give an optimal contribution (Cavanagh, 2014). In terms of discussing feminism issue within the United States, this discussion paper will focus on public's view toward women as political participants, women's right and its violations in the United States, and the solutions to fight against gender discrimination in the United States, especially in its political system.

\section{Women's Rights and Their Violations}

According to United Nations Human Right Office of the High Commissioner (2017), human rights are rights inherent to all human beings, regardless of their nationality, place of residence, sex, national or ethnic origin, color, religion, language, or any other status. Every human being is equally entitled to his or her human rights without discrimination. However, women, especially women in the United States, still experience violation of their rights every day. This can be attributed to the fact that the United States is one of the seven countries that has not ratified the International Convention on the Elimination of All Forms of Discrimination against Women (United Nations 2015). This led to various violation of gender-related rightsthat are based on gender. For example, the wage gap between men and women is has still been a widely debated topic topic until today. According to a research, a woman only makes 78 cents for every dollar earned by a man and such . The situation is even worse for African-American and Latin women that make even less, with 64 cents and 53 cents respectively (Biddle 2017). Thus, according to the aforementioned data, women are more likely to be poorer than men. In the context of United States, the gap in poverty rates between men and women is wider than anywhere else in the Western world (Cawthorne 2008). This wage gap problem does not only appear in the poor, but also on a various stratum of society.

Hollywood actresses have mentioned various times how they are paid less than their male colleagues, even though the woman is the main character in a movie (Berg 2015). Other than the problem of wage gap, women's healthcare is also denied many times in the 
United States. It is worsened by the fact that Affordable Care Act is on its way to be repealed, while actually many women still rely on it to treat conditions, such as endometriosis, ovarian cysts, test for sexually transmitted diseases, contraception, cancer screening and preventive services, post-sexual assault services, hormone therapy, treatment for heart disease and chronic illness, and mental health services (Barr 2017). Moreover, women's safety is also not guaranteed, because they are in constant danger of being raped or sexually assaulted. According to the data, 33\% of women in the United States are more likely to be abused (Live Your Dream 2017). Furthermore, according to the report of The United States Department of Justice (2013), 9 out of 10 rape victims are women and in 2013 only, there were 173,610 victims of sexual assault or rape. The data that has been mentioned before clearly shows how women's basic rights are highly violated in the United States.

The problem of gender equality does not only happen in the realms of healthcare and business, but also in the world of politics. This is evident in the United States government, where women are underrepresented and still not regarded equally as men. Nearly two and a half centuries after the United States gains its independence, there have been very few women who thrive in their political careers. Until this paper is written, there are only two women who have made it to the race to the presidency, namely Sarah Palin and Hillary Clinton (Han 2010). Nevertheless, no woman has ever been elected neither as president nor vice president in the United States. The discrimination of women in politics also happens at the regional level. Out of 50 states governors, only four of them are women (Live Your Dream 2017). As a matter of fact, women in the United States are not only marginalized within the executive branch but also in the other political branches. This can be clearly seen from the small number of women who are believed to hold any political position, whether in legislative or in judiciary branch. According to data collected by Catalyst (2017), women are still considered as minorities even in the 115th United States' Congress where women hold 83 of the 435 seats in the House of Representative and 21 of the 100 seats in the Senate. Furthermore, until 2017, not more than one woman has held a top leadership position, namelyThat woman is well known as Nancy Pelosi who was assigned a duty as the speaker of the House of Representative in 2007. Meanwhile, within the judicial branch, only three women have ever served as the United States Supreme Court, namely Sandra Day O'Connor (1981), Ruth Bader Ginsberg (1993), and Sonia Sotomayor (2009) (Han 2010). The authors do not 
deny that this situation has clearly improved compared to the 1950 s where women can only participate as campaign workers, but not as actual candidates. However, still, if women's circumstances are compared to men's in the government, women are still considered as minorities.

\section{Public's View toward Women as Political Participants}

Throughout the history of the United States, women have always been degraded in various aspects, including political participation. As written on the previous sub-chapter, women still receive numerous violations of rights until today. At the bottom of the problem, the violations of women's rights are highly related with public's view. Women have to face several stereotypes which have been constructed since a baby's gender is found out. Among a million of gender stereotypes about a female, the one that mostly debated by females is the statement that 'women should stay home while men go to work'. In line with this stereotype, some people with a traditional way of thinking also explicitly utter that 'women are not politician' (Brewer n.d.). The stereotypes are usually rooted in people's mind and transferred from generations to generationsfrom . In the end, those stereotypes affect people's view towards women, which people tend to generalize women's nature as feminine, weak, spoiled, sensitive, and meek (Ward 1996). The generalization of women's nature subsequently sparks the assumptions that women lack leadership personality and political capability. Therefore, most people assume that women are not capable enough to be a political leader.

As a matter of fact, the word leadership is a fluid terminology which change based on the context and situation (Burns 1978). However, leadership is generally defined as the ability to encourage, influence, or inspire others to act in pursuit of a common goal (Han 2010). However, a leadership is often linked to men and masculinity as opposed to women and their 'generalized' natures. The mindset of linking men and politics has thrived within the society all around the world, including in the United States. In the perspective of most Americans, a strong leadership is purely defined as the ability to exert one's will over a particular situation. As a result, this view of leadership creates a "double standard and double bind" for the women who serve as the leader and being delegated with political power (Rhode and Kellerman 2007). Indeed, it is undeniable that there is a construction of thought in most people's mind that women's capability in politics is subordinate when it is compared 
to men. Moreover, women are often placed in a lose-lose situation, where they will be viewed negatively if they exhibit leadership characteristics that are either too masculine (assertive which is seen as abrasive) or too feminine (soft or not tough enough to do the job). Furthermore, most women who maintain their career in politics are simply labeled negatives since "working mother" carries a bad connotation. It is viewed as neglecting their responsibilities to do the housework and take care of their families as a mother or as a wife (Han 2010).

In conclusion, the conceptualization of leadership as a male's inherent capability forms a barrier for women in politics. This barrier is not only in terms of campaigning for an office, but also in holding their current political authority (Han 2010). This barrier that prevents women from securing the top leadership role is often called as a glass ceiling due to its unseen and unsanctioned form (Hoyt 2010). Genuinely, within the United States policy-making process that emphasizes on power and aggressive competition, women are more likely to be downtrodden by the men, but by the minimum trust of the public. Since men are expected to be more competitive, strong, tough, decisive, and in control, most Americans think that male leaders fit better in the United States political system (Han 2010). Nevertheless, it has to be noted that the 'double standards and double bind' on women leaders are based on the female stereotypes which is merely a personal assumption with no theoretic explanation. Therefore, a reconsideration of women's contribution in politics should be categorized as an important agenda. Although most people assume that masculinity is attached to political leadership, the truth that effective leadership requires an androgynous combination of masculinity and femininity shows people that women's thoughts and roles on politics cannot be absolutely ignored (Hoyt 2010). As reported by the Pew Research (2016), permitting women to achieve top political position will give several clear advantages to Americans, since women are superior to men in term of compromising, persuasion, ethics, and honesty. Furthermore, the research also shows that women political officers are better than men on improving the quality of life for Americans and standing up for their beliefs despite political pressure (Pew Research 2016).

\section{The Call for A Fight against Gender Discrimination}

Seeing how serious the problem of women's right violation in the United States, especially in the political issue, we hereby propose 
some solutions to solve the problems. Firstly, we propose some sort of campaign to promote gender equality in the United States. The campaign can be done via social media, such as Twitter, Facebook, and Instagram, because those are the platforms used by a lot of people from various social strata. Therefore, the campaign hopefully would reach people from various backgrounds. However, we also recognize that there are people who do not use social media. Thus, we also propose a conventional campaign by spreading pamphlets or posters in public places where people would gather and see. In order to make this particular campaign successful, the contents should be designed as intriguing as possible. For the conventional campaign with posters, we suggest using bright colors and unique text font, so people will pay attention and start to show their interest. For the social media campaign, we recommend using hashtags with a short and memorable sentence that would explain the campaign well, such as \#WomenCanDoIt, \#WomenAreTheAnswer, or \#WomenRunTheWorld.

Second, we also propose to write an e-petition to the government, because it has been known as one of the best ways to influence the decision-making process (Macintosh 2004). The petition's content should demand the United States' government to treat women and men equally in every aspect of their lives. For example, Americans could demand their government to create an act that regulates equal payment between men and women. To narrow it down in the political aspect, the petition could ask the government to allocate an equal quota of women and men within the Congress. It would be better if the petition can be signed by as many people as possible since the number of signatures would represent the power of the petition. More signatures mean a greater chance of the government to actually consider the petition.

Lastly, we propose a peaceful march in the name of gender equality. The march could be done in public places, such as the Times Square in New York or in Washington, DC. For the march to be successful, a huge publication and coverage have to be done in order to invite more participants. Just like the number of signatures in the petition, the number of participants in the march will also determine the reaction of the government. For example, when President Donald Trump released his executive order on banning immigrants from some Muslim countries, the people of the United States reacted by doing marches in many states. These movements caught the government's attention and led them to cancel the executive order. 
In conclusion, what we are proposing is actually a movement with every American as the main participator. Movements have made great impacts throughout the history of United States, especially in cases of gender equality. Lily Ledbetter Fair Pay Restoration Act in 2009 allows victims of wage discrimination who are usually women to file a complaint to the government within 180 days of their last paycheck (Milligan 2017). In 2013, women can participate again in military combat after the restriction of women from combat roles was removed (Milligan, 2017). Today, the people of the United States are trying to achieve this success once again, but in the political field. Women should have the same opportunity as men. More women should sit on the Congress and make decisions that would make the United States better in the future. Women can do it, and if the people of the United States would join their forces and voice this petition louder, the goal would be achieved easily.

\section{Conclusion}

In conclusion, the authors argue gender inequality is still a problem in United States even with its status as a superpower with developed economy. The authors' research shows that discrimination towards women is still happening in various aspects of life, such as in everyday jobs and healthcare. Looking at its political system, the authors argue that the United States really need to make important changes in their political system. The changes in the United States' political system is crucial since there are still many flaws in the system, one of which is the gender violation that is still perceived as normal until today. In the political aspect, discrimination towards women is clearly presented by the small number of women who succeeded in their political careers. The failure for women to succeed is caused by public's view of women. The public sees women as feminine, weak, spoiled, sensitive and meek creatures, and therefore they do not have the ability to lead or make decisions rationally. However, the authors' research also shows that those views are incorrect, because women's leadership has been proven to give the United States varying advantages. The authors then decide to support the feminist movement to change the existing view on women. The change could be done in a lot of ways, such as by sending a petition to the government, by doing campaigns, or by doing a march. The movements are important to create a pro-women bureaucracy in the government and to raise the awareness that men and women are equal in every life aspect. However, the authors would like to stress 
the importance of awareness of the American citizens in order for these solutions to succeed. Awareness of gender inequality plays an important part for the society to work together and create a more equal United States.

\section{References}

\section{Online article}

Barr, Heather, 2017. "A Key Step Toward Ending Child Marriage in New York" [online]. in https://www.hrw.org/news/2017/03/o1/ key-step-toward-ending-child-marriage-new-york [accessed 14 June 2017].

Berg, Madeline, 2015. "Everything You Need to Know About the Hollywood Pay Gap" [online]. in https://www.forbes.com/ sites/maddieberg/2015/11/12/everything-you-need-to-knowabout-the-hollywood-pay-gap/\#18610a625cf1 [accessed 14 June 2017].

Biddle, Tabby, 2017. “Wait, Women Don't Have Equal Rights in the United States?” [online]. in http://www.huffingtonpost.com/ tabby-biddle/wait-women-dont-have-equa_b_6098120.html [accessed 13 June 2017].

Bremmer, Ian, 2015. "These Are the 5 Reasons Why the U.S. Remains the World's Only Superpower" [online]. in http:// time.com/3899972/us-superpower-status-military/ [accessed 13 June 2017].

Brewer, Holy, n.d. "List of Gender Stereotypes" [online]. in http:// www.healthguidance.org/entry/15910/1/List-of-GenderStereotypes.html [accessed 14 June 2017].

Catalyst, 2017. "Women in Government" [online]. in http://www. pewsocialtrends.org/2015/01/14/chapter-2-what-makes-agood-leader-and-does-gender-matter/ [accessed 14 June 2017].

Cavanagh, Casey, 2014. "Why We Still Need Feminism" [online]. in http://www.huffingtonpost.com/casey-cavanagh/why-we-stillneed-feminism_b_5837366.html [accessed 13 June 2017].

Cawthorne, Alexandra, 2008. "The Straight Facts on Women in 
Poverty" [online]. in https://www.americanprogress.org/ issues/women/reports/2008/10/08/5103/the-straight-factson-women-in-poverty/ [accessed 14 June 2017].

International Monetary Fund, 2007. "World Economic Outlook " [online]. in http://www.imf.org/external/Pubs/FT/ WEO/2007/o1/index. htm [accessed 20 February 2008].

Kamrany, NakeMand Catherine Robinson, 2012."TheGlobal Problem of Gender Inequality" [online]. in https://www.huffingtonpost. com/nake-m-kamrany/gender-inequality_b_1417535.html [accessed 18 July 2018].

Live Your Dream, 2017. "History of Women's Rights in America" [online]. in http://yourdream.liveyourdream.org/2017/03/ history-of-womens-rights-america/?gclid=CjwKEAjw9_j

Milligan,Susan, 2017. "SteppingThroughHistory"[online].inhttps:// www.usnews.com/news/the-report/articles/2017-01-20/ timeline-the-womens-rights-movement-in-the-us [accessed 14 June 2017].

Pew Research Centre, 2015. "Chapter 2: What Makes a Good Leader, and Does Gender Matter?" [online]. in http://www. pewsocialtrends.org/2015/01/14/chapter-2-what-makes-agood-leader-and-does-gender-matter/ [accessed 14 June 2017].

United Nations, 2015. "Women in US lagging behind in human rights, UN experts report after 'myth-shattering' visit" [online]. in http://www.un.org/apps/news/story.asp?NewsID=52797\#. WUGwALpuJjp [Accessed 14 June 2017].

United Nations Educational, Scientific, and Cultural Organization, 2003. “UNESCO's Gender Mainstreaming Implementation Framework: Baseline Definitions of Key Concepts and Terms" [online]. in http://www.unesco.org/new/fileadmin/ MULTIMEDIA/HQ/BSP/GENDER/PDF/1.\%2oBaseline\%20 Definitions\%20of\%2okey\%2ogender-related\%2oconcepts.pdf [accessed 18 July 2018].

United Nations Human Right Office of the High Commissioner, 2017. "What are Human Rights?" [online]. in http://www.ohchr.org/ EN/Issues/Pages/WhatareHumanRights.aspx [Accessed 14 June 2017]. 


\section{Book}

Burns, James MacGregor, 1978. Leadership. New York: Harper and Row.

Catalyst, 2017. Women in Government [online]. Available at: http:// www.pewsocialtrends.org/2015/01/14/chapter-2-what-makesa-good-leader-and-does-gender-matter/ [Accessed 14 June 2017].

Cavanagh, Casey, 2014. Why We Still Need Feminism. Huffington Post, [internet] 18 September. Available at: http://www. huffingtonpost.com/casey-cavanagh/why-we-still-needfeminism_b_5837366.html [Accessed 13 June 2017].

Cawthorne, Alexandra, 2008. The Straight Facts on Women in Poverty. Center of American Progress, [internet] 8 October. Available at: https://www.americanprogress.org/issues/ women/reports/2008/10/08/5103/the-straight-facts-onwomen-in-poverty/ [Accessed 14 June 2017].

Han, Lori Cox, 2010. Women and US Politics: The Spectrum of Political Leadership. London: Lynne Rienner Publisher

Jackson, Robert H., and Georg Sorensen, 2013. Introduction to International Relations. Oxford: Oxford University Press.

Rhode, Deborah and Barbara Kellerman, 2007. "Women and Leadership: The State of Play", in Rhode, Deborah and Barbara Kellerman (eds.), 2007. Women and Leadership: The State of Play and Strategies for Change. New York: Wiley. 2007

True, Jacqui, 2001. "Feminism", in Burchill, Scott et al., 2001. Theories of International Relations. California: Palgrave.

Ward, Julie K., 1996. Feminism and Ancient Philosophy. Routledge: New York.

\section{Journal}

Dea, Mulatu, 2016. "The Prospectus, Challenges, and Causes of Gender Disparity and its Implications for Ethiopia's 
Development: Qualitative Inquiry”, Journal of Education and Practice, 7 (4): 24-37.

Hoyt, Crystal L,. 2010. "Women, Men, and Leadership: Exploring the Gender Gap at the Top", Social and Personality Psychology Compass, 4 (7): 484-498.

Jayachandran, Seema, 2015. "The Roots of Gender Inequality in Developing Countries", Annual Review of Economics, 7 :63-88.

International Monetary Fund, 2007a. World Economic Outlook [online]. dalam http://www.imf.org/external/Pubs/FT/ WEO/2007/o1/index. htm [diakses 20 Februari 2008].

\section{Conference paper}

Brown, J., 2005. "Evaluating surveys of transparent governance", in 6th Global forum on reinventing government: towards participatory and transparent governance, 24-27 May. Seoul: Republic of Korea.

Jackson, Robert H., and Georg Sorensen, 2013. Introduction to International Relations. Oxford: Oxford University Press.

LiveYour Dream, 2017. HistoryofWomen's RightsinAmerica[online]. Available at: http://yourdream.liveyourdream.org/2017/03/ history-of-womens-rights-america/?gclid=CjwKEAjw9_

Macintosh, Ann, 2004. "Characterizing E-Participation in PolicyMaking"g,. In: IEEE Computer Society Press,in the 37th Hawaii International Conference on System Sciences, 5-8 January. . Hawaii: United States of America.

, United States of America, 5-8 January 2004. IEEE: New York.

Milligan, Susan, 2017. Stepping Through History. US News, [internet] 20 January. Available at: https://www.usnews.com/ news/the-eport/articles/2017-01-20/timeline-the-womensrights-movement-in-the-us [Accessed 14 June 2017].

Pew Research Centre, 2015. Chapter 2: What Makes a Good Leader, and Does Gender Matter? [online]. Available at: http://www. pewsocialtrends.org/2015/01/14/chapter-2-what-makes-agood-leader-and-does-gender-matter/ [Accessed 14 June 2017]. 
Rhode, Deborah and Barbara Kellerman. "Women and Leadership: The State of Play", in Women and Leadership: The State of Play and Strategies for Change. New York: Wiley. 2007

True, Jacqui, 2001. "Feminism", in Burchill, Scott et al., 2001. Theories of International Relations. California: Palgrave.

United Nations Department of Economic and Social Affairs (UNDESA), 2005. Equal Participation of Women and Men in Decision-Making Processes, with Particular Emphasis on Political Participation and Leadership. Addis-Ababa, Ethiopia 24-27 October 2005. United Nations: New York.Annual Report

United Nations Human Right Office of the High Commissioner, 2017. What are Human Rights? [online]. Available at: http:// www.ohchr.org/EN/Issues/Pages/WhatareHumanRights.aspx [Accessed 14 June 2017].

United Nations, 2015. Women in US lagging behind in human rights, UN experts report after 'myth-shattering' visit. UN News Centre, [internet] 11 December. Available at: http://www.un.org/apps/ news/story.asp?NewsID=52797\#.WUGwALpuJjp [Accessed 14 June 2017].

Ward, Julie K., 1996. Feminism and Ancient Philosophy. Routledge: New York.

World Economic Forum (WEF), 2016. Global Gender Gap Report 2016.

United Nations Department of Economic and Social Affairs (UNDESA), 2005. Equal Participation of Women and Men in Decision-Making Processes, with Particular Emphasis on Political Participation and Leadership.

United Nations Development Programme (UNDP), 2013. Humanity Divided: Confronting Inequality in Developing Countries. 